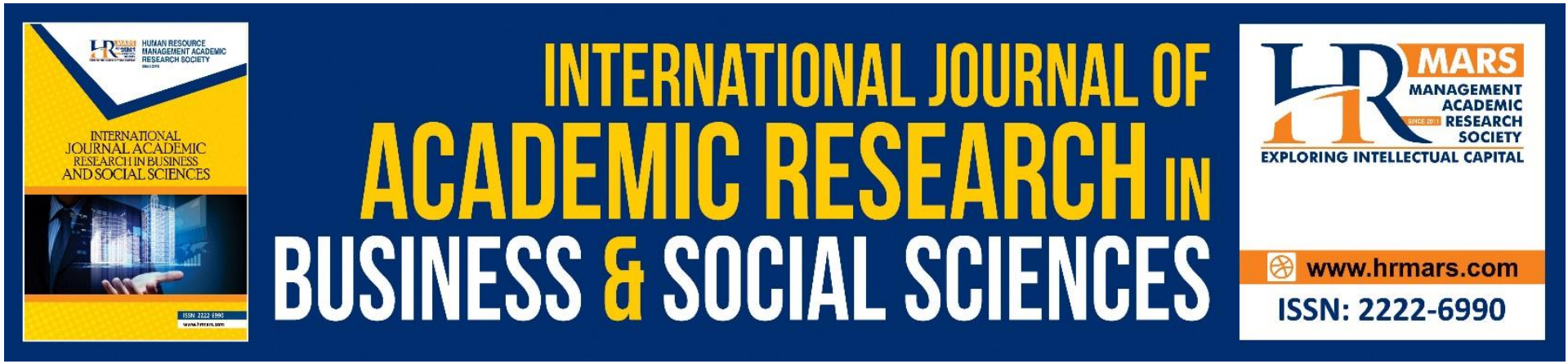

\title{
The Suitability of Institutional Arrangement and Policy Assessment Indicator in Malaysia's Land Administration System
}

\section{Salfarina Samsudin}

To Link this Article: http://dx.doi.org/10.6007/IJARBSS/v10-i11/8365

DOI:10.6007/IJARBSS/v10-i11/8365

Received: 14 September 2020, Revised: 20 October 2020, Accepted: 11 November 2020

Published Online: 26 November 2020

In-Text Citation: (Samsudin, 2020)

To Cite this Article: Samsudin, S. (2020). The Suitability of Institutional Arrangement and Policy Assessment Indicator in Malaysia's Land Administration System. International Journal of Academic Research in Business and Social Sciences, 10(11), 1414-1425.

Copyright: (c) 2020 The Author(s)

Published by Human Resource Management Academic Research Society (www.hrmars.com)

This article is published under the Creative Commons Attribution (CC BY 4.0) license. Anyone may reproduce, distribute, translate and create derivative works of this article (for both commercial and non-commercial purposes), subject to full attribution to the original publication and authors. The full terms of this license may be seen at: http://creativecommons.org/licences/by/4.0/legalcode

Vol. 10, No. 11, 2020, Pg. 1414 - 1425

Full Terms \& Conditions of access and use can be found at http://hrmars.com/index.php/pages/detail/publication-ethics 


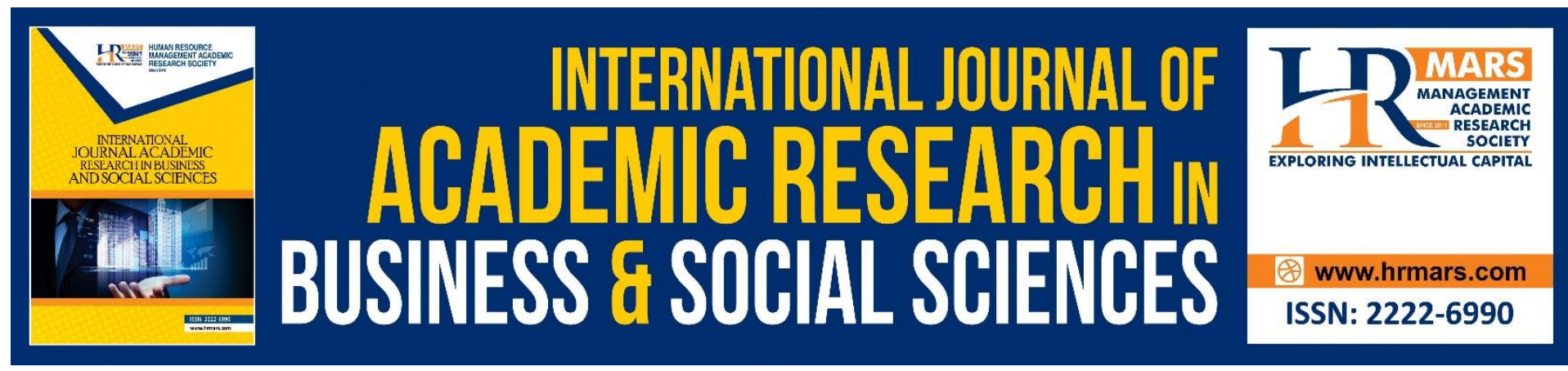

\title{
The Suitability of Institutional Arrangement and Policy Assessment Indicator in Malaysia's Land Administration System
}

\author{
Salfarina Samsudin \\ Department of Real Estate, Faculty of Built Engineering and Surveying, Universiti Teknologi \\ Malaysia, 81310 Johor Bahru, Johor, Malaysia
}

\begin{abstract}
A quality assessment framework that assesses the performance of institutional arrangement of land administration is essentially needed considering the framework is where the legal process and property rights are ensured. Land Governance Assessment Framework (LGAF) by World Bank is developed as a diagnostic instrument to assess country's land administration system at national or sub-national level. This study explored the appropriateness of this assessment framework by interviewing experts from Department of Land and Mines, Department of Surveying and Mapping in Penang Land and Mines Office, and Department of Town Planning and Consumer Association of Penang to determine the suitability based on twelve indicators of institutional arrangement and policy highlighted in LGAF. The result shows that, out of twelve indicators, only eleven indicators are highly suitable to be evaluate by Malaysia's land administration system. Through this study, a formal land administration system can be supported and guided via the scheduled evaluations based on the indicators which will be a beneficial for land authorities.
\end{abstract}

Keywords: Land Administration, Institutional Arrangement, Policy Assessment, Indicator, Land Governance Assessment Framework

\section{Introduction}

Institutional framework of land administration system ensures the legal basis necessary for the process, respecting property rights, and guaranteeing the property's protection (Auzins \& Kapostins, 2012). Ali et al. (2014) specified that institutional structure is a key determinant of the land administration system efficiency with a clear internal and external flow of information. Besides, land administration system includes land settlement, land survey, land registration, land valuation, land control, infrastructure, and utilities. Williamson $\&$ Grant (2000) regarded land administration institution as a rule of the game according to accepted law and regulations. In this case, organizations in land administration are recognized as a key player that guarantees smooth operation of the institutions involved. In most countries, the institutional arrangement of land administration is commonly influenced by the country's background, depending by the type of system, whether it is decentralized, deconcentrated, or centralized (Williamson, 2001). 
The institutional arrangement of land administration touches on many issues, i.e. community participation, governance, sustainability, and decision making. Other than that, issues related to the review of the institutional arrangement of land administration include (i) organizational structure, roles, and responsibilities of the institutions providing the core land administration functions, i.e. registration, surveying, and mapping, (ii) decentralization of land administration agencies, (iii) linkages of the core land administration function to other land sector agencies and functions, and (iv) role of the private sector (Burns et al., 2006). Bandeira et al. (2010) illustrated that the ineffectiveness of institutional design leads to consequences e.g. thin land formal market, high inability to enforce regulation, and high land tax evasion. Bennett et al. (2008) identified the legal and institutional conflicts arising from poorly designed, weakly administered, and inappropriate institutional arrangement.

Following the aforementioned issues, it is therefore important to have a quality assessment framework that assesses the performance of institutional arrangement because land administration activities require a more comprehensive understanding of the principles of institutional arrangement (Burns et al., 2006; Mughal, 2019). Next, institutional arrangement in land administration system needs an effective organization to enhance credibility in the society. Inadequate policy implementation can be recognized if assessment on the performance of institutional arrangement of land administration system does not exist. In this case, ongoing studies are conducted to evaluate different methods to measure the success of land administration system. Steudler (2004) determined that the performance of land administration system is currently being evaluated by different organizations to assess the system for many different purposes, e.g. Table 1 illustrates the land governance assessment framework or in short, LGAF, which has been analyzed by World Bank as a diagnostic tool for land administration system in 50 countries (Deininger et al., 2011). This study explored and analyzed the appropriateness of LGAF to evaluate the suitability of institutional arrangement and policy indicator in Malaysia's land administration system.

Table 1. List of Countries Categorized by Continent

\begin{tabular}{|c|c|c|}
\hline Continents & \multicolumn{2}{|c|}{ Countries } \\
\hline Africa & $\begin{array}{l}\text { - } \text { Benin } \\
\text { - Burkina Faso } \\
\text { - } \text { Burundi } \\
\text { - } \text { Cameroon } \\
\text { - Cape Verde } \\
\text { - } \text { Dem. Republic of the Congo } \\
\text { - Egypt } \\
\text { - Ethiopia } \\
\text { - The Gambia } \\
\text { - Ghana } \\
\text { - Guinea } \\
\text { - Kenya } \\
\text { - Lesotho } \\
\text { - Liberia } \\
\text { - Madagascar }\end{array}$ & $\begin{array}{l}\text { - Malawi } \\
\text { - Mali } \\
\text { - Mauritania } \\
\text { - Nozambique } \\
\text { - Nigeria } \\
\text { - Rwanda } \\
\text { - Senegal } \\
\text { - Sienna Leone } \\
\text { - South Africa } \\
\text { - Sudan Sudan } \\
\text { - Tanzania } \\
\text { - Uganda } \\
\text { - Zambia }\end{array}$ \\
\hline $\begin{array}{l}\text { Central } \\
\text { Europe }\end{array}$ & $\begin{array}{l}\text { - } \text { Azerbaijan } \\
\text { - } \quad \text { Croatia } \\
\end{array}$ & $\begin{array}{l}\text { - } \text { Moldova } \\
\text { - } \text { Romania } \\
\end{array}$ \\
\hline
\end{tabular}




\begin{tabular}{|l|ll|}
\hline & $\bullet$ Georgia & $\bullet$ Ukraine \\
\hline Latin & $\bullet$ Brazil & $\bullet$ Honduras \\
& $\bullet$ Colombia & $\bullet$ Peru \\
\hline Asia & $\bullet$ Guatemala & $\bullet$ Myanmar \\
& $\bullet$ Cambodia & $\bullet$ Philippines \\
& $\bullet$ India & $\bullet$ Timor-Leste \\
& $\bullet$ Indonesia & $\bullet$ Vietnam \\
& $\bullet$ Kyrgyz Republic & $\bullet$ Dubai \\
\hline Middle East & $\bullet$ Laos &
\end{tabular}

Source: (Deininger et al., 2011)

\section{Institutional Arrangement and Policy Assessment}

Assessment is needed in any case where changes are considered, and an assessment portfolio has the greatest benefit to the organizations by giving necessary feedbacks into policy planning, programming, and budgetary process (Spilsbury et al., 2014). Assessment also reflects whether an organization is systematic or not (Eo, 2010). Baizerman (2012) argued that the purpose of an assessment is to improve organizational practices. Cousins et al. (2014) believed that assessment is a systematic inquiry used in the formulation of judgment about merit, value or significance, and in support of decision making. It is also closely related with the terms utilization, impact, and influence (Daigneault, 2014).

Eo (2010) concluded that an assessment provides evidence-based information that are credible and enables the findings into decision making process. Spilsbury et al. (2014) specified that the findings in an assessment play an important role to secure organizational financial resources. Ingraham (2013) discovered that assessment helps to discover how a program is running, what the program is trying to do, and if the outcomes are similar to the stated goals and objectives. Likewise, assessment provides evidence of effective performance in achieving important outcomes and benefits (Spilsbury et al., 2014). Assessment also determines the relevance, efficiency, effectiveness, impact, and sustainability of the interventions and contributions of the involved partners (Eo, 2010). Jabot et al. (2011) specified that assessment is an exercise that drives towards positive values by effects.

Findings from assessment are used to improve program, organizational structure, and process on an ongoing basis (McCoy et al., 2014). Program assessment is also a good way of repair to prevent and control situations which enhance opportunity and possibility. Assessments of activities are usually undertaken to review the logic and to determine the progress towards results (Spilsbury et al., 2014). In short, assessment is vital as it helps to improve a particular system by learning from situations that abstain the attainment of goals.

In discussing the governance approach to land administration, Table 2 shows that Deininger et al. (2011) have determined five thematic areas that have to be considered to achieve a successful governance. In this case, they found a specific role for public institutions in the land sector for them to increase good governance. Furthermore, understanding the roles and responsibilities of land governance institutions may contribute to the legal frameworks, policies, and practices regarding land and land use. 
Table 2. Five Thematic Areas in LGAF

\begin{tabular}{|c|c|}
\hline Thematic Area & Explanation \\
\hline $\begin{array}{l}\text { Legal and } \\
\text { institutional } \\
\text { framework }\end{array}$ & $\begin{array}{l}\text { Indicators related to the legal and institutional framework are } \\
\text { designed to help policy makers assess: } \\
\text { - The extent to which the range of existing land rights is legally } \\
\text { recognized. } \\
\text { - The level of documentation and enforcement and the cost of } \\
\text { enforcing or gradually upgrading these rights. } \\
\text { - Whether the regulation and management of land involve } \\
\text { institutions with clear mandates and policy process that is } \\
\text { transparent and equitable. }\end{array}$ \\
\hline $\begin{array}{l}\text { Land use } \\
\text { planning, } \\
\text { management, } \\
\text { and taxation }\end{array}$ & $\begin{array}{l}\text { The purposes of assessing this category are: } \\
\text { - Land use restrictions are justified on the basis of the public } \\
\text { interest. } \\
\text { - Necessary exemptions are granted promptly and transparently. } \\
\text { - The process for land use planning is efficient. } \\
\text { efficiently collected. }\end{array}$ \\
\hline & $\begin{array}{l}\text { A focus on public land management aims to help assess the extent to } \\
\text { which: } \\
\text { - Public landholdings are justified and transparently inventoried } \\
\text { and managed; } \\
\text { - Expropriation procedures are applied in the public interest } \\
\text { through clear, transparent, and fair process involving the } \\
\text { compensation of all those who lose rights. } \\
\text { - The transfer or devolution of state land is transparent and } \\
\text { monitored. }\end{array}$ \\
\hline $\begin{array}{l}\text { Public provision } \\
\text { of land } \\
\text { information }\end{array}$ & $\begin{array}{l}\text { Indicators related to this category assess: } \\
\text { - Whether land information systems provide sufficient, relevant, } \\
\text { and up- to-date data on land ownership to the general public. } \\
\text { - Whether land administration services are accessible, } \\
\text { affordable, and sustainable. }\end{array}$ \\
\hline $\begin{array}{l}\text { Dispute } \\
\text { resolution and } \\
\text { conflict } \\
\text { management }\end{array}$ & $\begin{array}{l}\text { This fifth set of indicators can be used to assess: } \\
\text { - Whether a country has affordable, clearly defined, transparent, } \\
\text { and unbiased mechanisms for the resolution of land disputes. } \\
\text { - Whether these mechanisms function effectively in practice. }\end{array}$ \\
\hline
\end{tabular}

Source: (Deininger et al., 2011)

The LGAF process is guided by a framework of land governance indicators in the five thematic areas listed above divided into nine focus areas; each is divided into three to four dimensions (Table 3 ) in which rankings are assigned by expert panels based on prerecorded answers (on a scale from $A$ to $D$ ) drawn upon global experiences. Through a consensual and participatory assessment by local experts of this core set of indicators, the LGAF serves to map out key information on land governance and define actionable paths for policy interventions; all in a contextualized and country-driven manner. 
Table 3. List of Focus Areas and Indicators

\begin{tabular}{|c|c|}
\hline Focus Area & Indicators \\
\hline $\begin{array}{l}\text { Land Rights } \\
\text { Recognition }\end{array}$ & $\begin{array}{l}\text { Indicator 1: Recognition of a continuum of rights } \\
\text { Indicator 2: Respect for and enforcement of rights }\end{array}$ \\
\hline $\begin{array}{l}\text { Rights to Forest and } \\
\text { Common Lands \& } \\
\text { Rural Land Use } \\
\text { Regulations }\end{array}$ & $\begin{array}{l}\text { Indicator 1: Rights to forest and common lands } \\
\text { Indicator 2: Effectiveness and equity of rural land use regulations }\end{array}$ \\
\hline $\begin{array}{l}\text { Urban Land Use, } \\
\text { Planning, and } \\
\text { Development }\end{array}$ & $\begin{array}{l}\text { Indicator 1: Restrictions on rights } \\
\text { Indicator 2: Transparency of land use restrictions } \\
\text { Indicator 3: Efficiency in the urban land use planning process } \\
\text { Indicator 4: Speed and predictability of enforcement of restricted } \\
\text { land uses } \\
\text { Indicator 5: Tenure regularization schemes in urban areas }\end{array}$ \\
\hline $\begin{array}{l}\text { Public Land } \\
\text { Management }\end{array}$ & $\begin{array}{l}\text { Indicator 1: Identification of public land and clear management } \\
\text { Indicator 2: Justification and time-efficiency of acquisition processes } \\
\text { Indicator 3: Transparency and fairness of acquisition procedures }\end{array}$ \\
\hline $\begin{array}{l}\text { Transfer of Large } \\
\text { Tracts of Land to } \\
\text { Investors }\end{array}$ & $\begin{array}{l}\text { Indicator 1: Transfer of public land to private use follows a clear, } \\
\text { competitive process and payments are collected } \\
\text { Indicator 2: Private investment strategy } \\
\text { Indicator 3: Policy implementation is effective, consistent and } \\
\text { transparent } \\
\text { Indicator 4: Contracts involving public land are public and accessible }\end{array}$ \\
\hline $\begin{array}{l}\text { Public Provision of } \\
\text { Land Information: } \\
\text { Registry and Cadastre }\end{array}$ & $\begin{array}{l}\text { Indicator 1: Mechanisms for recognition of rights } \\
\text { Indicator 2: Completeness of the land registry } \\
\text { Indicator 3: Reliability of registry information } \\
\text { Indicator 4: Cost-effectiveness and sustainability of land } \\
\text { administration services } \\
\text { Indicator 5: Fees are determined transparently }\end{array}$ \\
\hline $\begin{array}{l}\text { Land Valuation and } \\
\text { Taxation }\end{array}$ & $\begin{array}{l}\text { Indicator 1: Transparency of valuations } \\
\text { Indicator 2: Collection efficiency }\end{array}$ \\
\hline Dispute Resolution & $\begin{array}{l}\text { Indicator 1: Assignment of responsibility } \\
\text { Indicator 2: The share of land affected by pending conflicts is low } \\
\text { and decreasing }\end{array}$ \\
\hline $\begin{array}{l}\text { Institutional } \\
\text { Arrangements and } \\
\text { Policies }\end{array}$ & $\begin{array}{l}\text { Indicator 1: Clarity of mandates and practice } \\
\text { Indicator 2: Equity and non-discrimination in the decision-making } \\
\text { process }\end{array}$ \\
\hline
\end{tabular}

Source: (Deininger et al., 2011)

In this study, the focus area is on institutional arrangement and policy with two indicators and twelve dimensions. Institutional framework is useful in identifying if the regulation and management of land involve institutions with clear mandates and policy process that are transparent and equitable (Deininger et al., 2011). The two indicators are:

a) Clarity of Institutional Mandates 
Institutional structure reflects the relationship between the actors in land administration transaction (Hagedorn, 2002). Transaction costs will increase because of unclear or overlapping mandates and functions. It can create a discretion of good governance (Deininger et al., 2011). Moreover, the existence of multiple organizations with each legislation power impacts on land administration cycle (Burns et al., 2006). Based on Hsu et al. (2013), lack of resources and weak legal framework increase the problems of property ownership, poor land management and institution coordination, and imbalance decision making between national policy and local decision. These can lead to the failure of good land administration system (Auzins \& Kapostins, 2012). There are five dimensions under this indicator respectively; (i) land policy formulation where the implementation and arbitration are separated to avoid conflict of interest, (ii) responsibilities of the ministries and agencies dealing with land do not overlap (horizontal), (iii) administrative (vertical) overlap is avoided, (iv) land rights and use information are shared by public institutions and key parts are regularly reported and publicly accessible, and ( $v$ ) overlaps of rights based on tenure typology are minimal and do not cause friction or dispute.

\section{b) Equity and Nondiscrimination in the Decision-Making Process}

Special interest groups are backed by some policy framework guiding institutional activities (Deininger et al., 2011). Equity is the success of an adaptation action (Whitehead \& Tsikata, 2003). Deere (2003) stated that nondiscrimination against women in land titling happens because women are considered as rural workers rather than the traditional designation "housewife". Seven dimensions listed in this indicator are; (i) land policies and regulations are developed in a participatory manner involving all relevant stakeholders, (ii) land policies address equity and poverty reduction goals (progress towards these is publicly monitored), (iii) land policies address ecological and environmental goals (progress towards these is publicly monitored), (iv) implementation of land policy is costed, matched with benefits, and adequately resourced, (v) regular public reporting indicating progress in policy implementation, (vi) land policies help to improve land use by low-income groups and those experiencing injustice, and (vii) land policies proactively and effectively reduce future disaster risk.

\section{Methodology of Study}

This study used primary and secondary data for the analysis. Primary data were collected via interviews consist of experts from Department of Land and Mines, Department of Surveying and Mapping in Penang Land and Mines Office, and Department of Town and Planning of Penang and Consumer Association of Penang, while secondary data were collected from the analysis of the relevant statutes, rules, regulations, books, reviews of previous research works as well as related journals. This study specifically used data analysis, writing method through revision, and reading and listening to recording data collected during interviews. This study also initially analyzed the interviewees' perceptions of the suitability of the indicators and dimensions of institutional arrangement and LGAF policies according to Malaysia context. 


\section{Results and Discussion}

Based on the interviewees' reviews, discussions, and opinions, all the listed indicators and dimensions are appropriate approach to assess the institutional arrangement of Malaysia's land administration system. Table 4 summarizes the discussions among the interviewees about the indicators and dimensions.

Table 4. Summary of Interviews based on Indicators

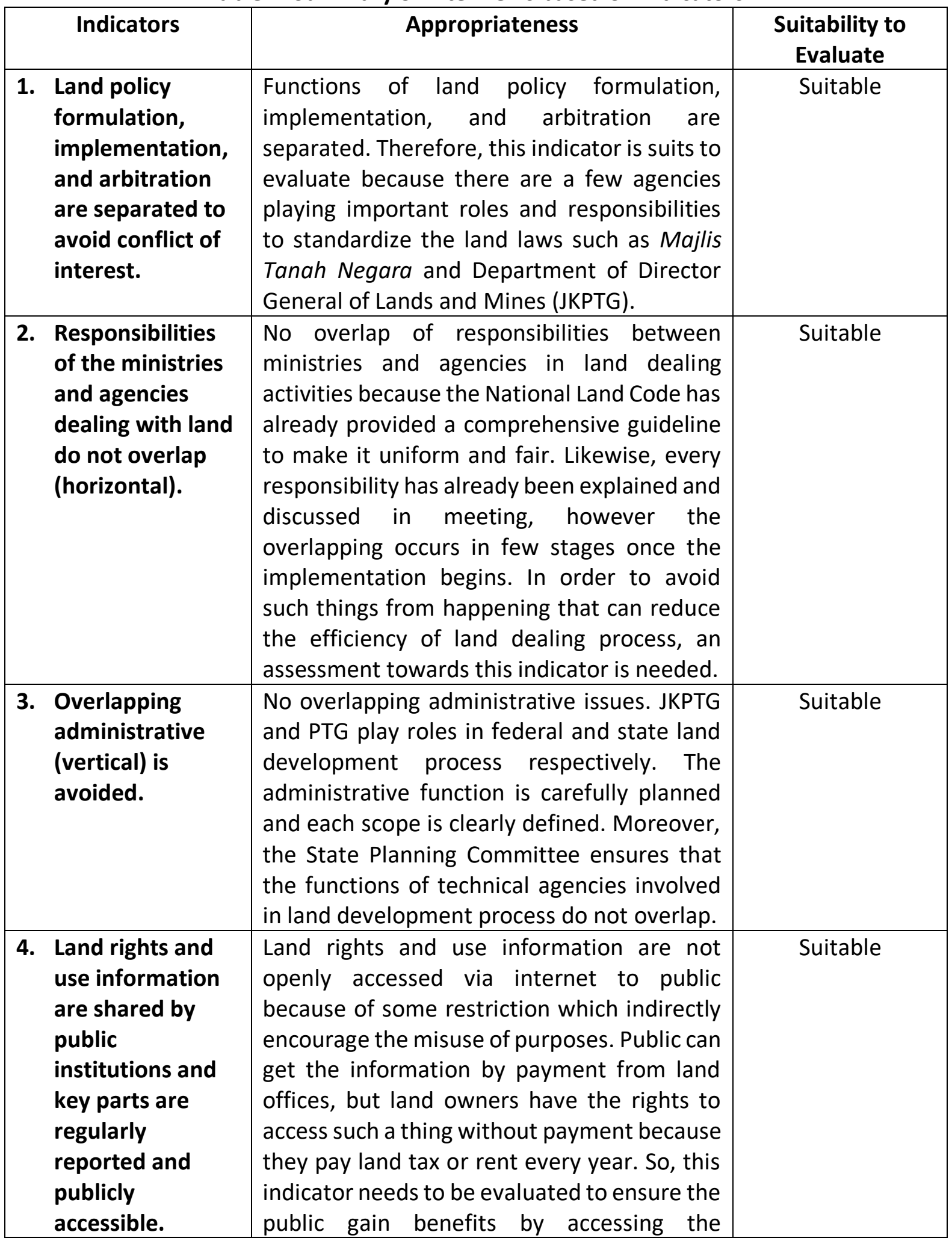




\begin{tabular}{|c|c|c|c|}
\hline & & $\begin{array}{l}\text { information. Additionally, by this sharing of } \\
\text { information, people can be made aware with } \\
\text { any projects developed by local authority. }\end{array}$ & \\
\hline & $\begin{array}{l}\text { Overlaps of rights } \\
\text { (based on tenure } \\
\text { typology) are } \\
\text { minimal and do } \\
\text { not cause friction } \\
\text { or dispute. }\end{array}$ & $\begin{array}{l}\text { Overlaps of rights causes double alienation } \\
\text { and fraud. This sometimes happens because } \\
\text { of unwritten will, hence may cause disputes } \\
\text { among family and relatives. However, } \\
\text { although the land tenure is bonded by } \\
\text { indefeasibility as stated in National Land } \\
\text { Code, the case still happens. Therefore, it is } \\
\text { better to evaluate this indicator for an } \\
\text { efficient land administration system. }\end{array}$ & Suitable \\
\hline & $\begin{array}{l}\text { Land policies and } \\
\text { regulations are } \\
\text { developed in a } \\
\text { participatory } \\
\text { manner involving } \\
\text { all relevant } \\
\text { stakeholders. }\end{array}$ & $\begin{array}{l}\text { The process of creating or amending land } \\
\text { policies and regulations involves special } \\
\text { bodies such as lawyer, surveyor, planner, and } \\
\text { valuer. There will be selecting committee to } \\
\text { develop land policies and regulations that } \\
\text { involves all relevant stakeholders. }\end{array}$ & Suitable \\
\hline & $\begin{array}{l}\text { Land policies } \\
\text { address equity } \\
\text { and poverty } \\
\text { reduction goals } \\
\text { (progress } \\
\text { towards these is } \\
\text { publicly } \\
\text { monitored). }\end{array}$ & $\begin{array}{l}\text { The equity assessment cannot be address in } \\
\text { Penang because it relies on purchasing power } \\
\text { with its uneven population. It has already } \\
\text { become private ownership in comparison to } \\
\text { other types of ownership. In addition, a few } \\
\text { monitors on reduction goal progress such as } \\
\text { FELDA Group Settlement Act (GSA) is } \\
\text { considered as a policy that helps the FELDA } \\
\text { residents. }\end{array}$ & $\begin{array}{l}\text { Not suitable for } \\
\text { address equity but } \\
\text { suitable for } \\
\text { poverty reduction } \\
\text { evaluation }\end{array}$ \\
\hline & $\begin{array}{l}\text { Land policies } \\
\text { address } \\
\text { ecological and } \\
\text { environmental } \\
\text { goals (progress } \\
\text { towards these is } \\
\text { publicly } \\
\text { monitored). }\end{array}$ & $\begin{array}{l}\text { There is a major concern about issues } \\
\text { regarding environment because it is a } \\
\text { primary requirement. Usually the state's } \\
\text { guidelines meet the environmental aspects. } \\
\text { Besides, ecological and environmental goals } \\
\text { are suitable to be evaluated because act of } \\
\text { environment has underlined the } \\
\text { environmental regulations in order to get } \\
\text { approval from local authority. This term is } \\
\text { rarely followed and authority should know } \\
\text { that the effects of development cannot be } \\
\text { perceived immediately. For example, } \\
\text { according to experts, the effects of land } \\
\text { reclamation take time and it should be } \\
\text { monitor after a long time of period, hence } \\
\text { this indicator is suitable to be assessed. }\end{array}$ & Suitable \\
\hline & $\begin{array}{l}\text { The } \\
\text { implementation } \\
\text { of land policy is }\end{array}$ & $\begin{array}{l}\text { Implementation of land policy that matches } \\
\text { with public benefits should be evaluated } \\
\text { because sometimes the implementation is }\end{array}$ & Suitable \\
\hline
\end{tabular}




\begin{tabular}{|l|l|l|}
\hline $\begin{array}{l}\text { costed, matched } \\
\text { with benefits, } \\
\text { and adequately } \\
\text { resourced. }\end{array}$ & $\begin{array}{l}\text { not beneficial towards public, hence this } \\
\text { indicator is very important. }\end{array}$ & \\
\hline $\begin{array}{l}\text { 10. There is a regular } \\
\text { and public } \\
\text { reporting } \\
\text { indicating the } \\
\text { progress in policy } \\
\text { implementation. }\end{array}$ & $\begin{array}{l}\text { Discussion via meeting with the state's Chief } \\
\text { Minister and Exco is one of the mechanisms } \\
\text { to indicate the policy implementation } \\
\text { reporting about e-Tanah implementation is } \\
\text { also a method to understand public critics on } \\
\text { land matter. There is no general indicating } \\
\text { process, hence this should be used as an } \\
\text { indicator. }\end{array}$ & Suitable \\
\hline $\begin{array}{l}\text { 11. Land policies help } \\
\text { to improve land } \\
\text { use by low- } \\
\text { income groups } \\
\text { and those who } \\
\text { experienced } \\
\text { injustice. }\end{array}$ & $\begin{array}{l}\text { Low-income groups and injustice need to be } \\
\text { evaluated. Sometimes the purposes of land } \\
\text { policies do not meet their objectives. For } \\
\text { example, there are no facilities for children in } \\
\text { low-cost houses that are specially built for } \\
\text { low-income groups. Hence, this must be } \\
\text { reconsidered and assessed for the sake of } \\
\text { low-income groups. }\end{array}$ \\
\hline $\begin{array}{l}\text { 12. Land policies } \\
\text { proactively and } \\
\text { effectively reduce } \\
\text { future disaster } \\
\text { risk. }\end{array}$ & $\begin{array}{l}\text { Environmental Impact Assessment (EIA), } \\
\text { however they should be monitored on a } \\
\text { particular area after development. Plus, } \\
\text { there is a perfect policy enforcement which } \\
\text { proactively and effectively reduces future } \\
\text { disaster risks, however lacking in } \\
\text { implementation makes the scenario worsen } \\
\text { off. Hence, this indicator suits to be } \\
\text { evaluated. }\end{array}$ & Suitable \\
\hline
\end{tabular}

Through the table, there are eleven indicators based on institutional arrangement and policy indicator that are highly recommended and suitable to appropriately adopt in Malaysia land administration system evaluation. The suitable indicators are heavily opinionated from the interviewees referring to the current implementation of Malaysia's land administration system.

\section{Conclusion}

This study analyzed the suitability and appropriateness of institutional arrangement and policy indicator in Malaysia's land administration system using the state of Penang as a case study. Interviewees gave reasons about the importance of the listed indicators and dimensions towards achieving efficiency in the land administration system. The assessments of institutional arrangement, as well as policy indicator and its dimensions have broadly improved the country's land governance and land administration performance. 


\section{Acknowledgement}

The author is grateful for the support and assistance given by the research members group, Longgeni Annamalai, Robiah Suratman and Khadijah Hussin to perform and conduct this research. This work was supported by a research grant endowed by the Malaysia's Ministry of Higher Education via: Research Management Centre (RMC), Universiti Teknologi Malaysia (Vot No. Q.J130000.2627.10J47). This support is gratefully acknowledged.

\section{Corresponding Author}

Salfarina Samsudin

Department of Real Estate, Faculty of Built Environment and Surveying, Universiti Teknologi Malaysia, 81310 Johor Bahru, Johor, Malaysia.

Email: salfarina@utm.my

\section{References}

Auzins, A., \& Kapostins, E. (2012). New Land Management Law for Providing a Sustainable Land Management in the Republic of Latvia. publication. editionName, 1-15.

Baizerman, M. (2012). Introduction. Evaluation and Program Planning, 35(1), 139-147.

Bandeira, P., Sumpsi, J. M., \& Falconi, C. (2010). Evaluating land administration systems: A comparative method with an application to Peru and Honduras. Land Use Policy, 27(2), 351-363.

Bennett, R., Wallace, J., \& Williamson, I. (2008). Organising land information for sustainable land administration. Land Use Policy, 25(1), 126-138.

Burns, T., Grant, C., Nettle, K., Brits, A. M., \& Dalrymple, K. (2006). Land administration reform: indicators of success. Future Challenges.

Cousins, J. B., Goh, S. C., Elliott, C., Aubry, T., \& Gilbert, N. (2014). Government and voluntary sector differences in organizational capacity to do and use evaluation. Evaluation and Program Planning, 44, 1-13.

Daigneault, P. M. (2014). Taking stock of four decades of quantitative research on stakeholder participation and evaluation use: A systematic map. Evaluation and program planning, 45, 171-181.

Deere, C. D. (2003). Women's land rights and rural social movements in the Brazilian agrarian reform. Journal of Agrarian Change, 3(1-2), 257-288.

Deininger, K., Selod, H., \& Burns, A. (2011). The Land Governance Assessment Framework: Identifying and monitoring good practice in the land sector. The World Bank.

Eo, G. (2010). The GEF Monitoring and Evaluation Policy 2010. Evaluation Document No.4: Global Environment Facility Evaluation Office. Retrieved from: https://www.gefieo.org/sites/default/files/ieo/evaluations/gef-me-policy-2010eng.pdf \

Glesne, C. (2011). Becoming Qualitative Researchers: An Introduction. Boston: Pearson.

Hagedorn, K., Arzt, K., \& Peters, U. (2002). Institutional arrangements for environmental cooperatives: a conceptional framework. Hagedorn, Konrad (Hg.) (2002): Environmental Co-operation and Institutional Change. Edward Elgar, Cheltenham, 3-25.

Hagedorn, K., Arzt, K., \& Peters, U. (2002). Institutional arrangements for environmental cooperatives: a conceptional framework. Hagedorn, Konrad (Hg.) (2002): Environmental Co-operation and Institutional Change. Edward Elgar, Cheltenham, 3-25.

Youker, B. W., Ingraham, A., \& Bayer, N. (2014). An assessment of goal-free evaluation: Case studies of four goal-free evaluations. Evaluation and program planning, 46, 10-16. 
Jabot, F., Turgeon, J., \& Carbonnel, L. (2011). The evaluation of the PACA regional public health plan: Reconciling the managerial, scientific and democratic finalities. Evaluation and program planning, 34(3), 196-205.

Mughal, H. A. (2019). Support at Work and its Relationship with Employee Performance:

Critical Insights for Early Scholars. Annals of Contemporary Developments in Management \& HR (ACDMHR), 1(3), 16-21.

Lee, N., \& Lings, I. (2008). Doing Business Research: A Guide to Theory and Practice. London: SAGE Publications Ltd.

McCoy, A., Rose, D., \& Connolly, M. (2014). Approaches to evaluation in Australian child and family welfare organizations. Evaluation and program planning, 44, 68-74.

Sekaran, U., \& Bougie, R. (2009). Research Methods for Business: A Skill Building Approach. United Kingdom: John Wiley \& Sons Ltd.

Spilsbury, M. J., Norgbey, S., \& Battaglino, C. (2014). Priority setting for evaluation: Developing a strategic evaluation portfolio. Evaluation and program planning , 46, 47-57.

Steudler, D. (2004). A framework for the evaluation of land administration systems (Doctoral dissertation). University of Melbourne.

Whitehead, A., \& Tsikata, D. (2003). Policy discourses on women's land rights in Sub-Saharan Africa: The implications of the re-turn to the Customary. Journal of Agrarian Change, 3(12), 67-112.1

Williamson, I. P. (2001). Land administration "best practice" providing the infrastructure for land policy implementation. Land Use Policy, 18(4), 297-307.

Williamson, I. P., \& Grant, D. (2000). The United Nations-International Federation of SurveyorsDeclaration on Land Administration for Sustainable Development.

Zahir, A., Tuladhar, A. M., Zevenbergen, J. A., \& Bhatti, M. A. (2014). Implementing total quality management concepts to land administration system in Pakistan. American journal of rural development, 2(4), 74-80. 